\title{
CORRIGENDUM
}

\section{Reconstructing desecuritisation:}

\section{the normative-political in the Copenhagen} School and directions for how to apply it CORRIGENDUM

The publishers regret that a number of small errors were published in 'Reconstructing desecuritisation: the normative-political in the Copenhagen Shool and directions for how to apply it' ${ }^{1}$

On p. 527, the quote by Aradau in paragraph two should correctly read 'a Foucauldian-inspired desecuritizing move'.

On p. 534 the last sentence of the second paragraph should read: Wæver's insistence on there being instances, where we would indeed want to securitise, also leads him to criticise 'hard-core' post-structuralists, who seek to open up, avoid making choices, and who recommends 'living dangerously'.

In the Rearticulation paragraph on pp. 542-3, the two instances of 'change stabilisation through' should read 'change through stabilisation'.

The year range given for the wars discussed in the second paragraph should read 1864 (not as it currently does, 1864-4)

Fn. 85 should read Behnke, 'No Way Out', p. 65, and fn. 86; Ibid., p. 64.

\section{References}

${ }^{1}$ Lene Hansen, 'Reconstructing desecuritisation: the normative-political in the Copenhagen School and directions for how to apply it', Review of International Studies, 38:3 (2012), pp. 525-546. 